Peter Jones*

Daphne Comfort*

David Hillier ${ }^{* * *}$
UDK 331.1:69 (410)

Preliminary paper

Prethodno priopćenje

\title{
CORPORATE SOCIAL RESPONSIBILITY AND THE UK CONSTRUCTION INDUSTRY
}

\begin{abstract}
This paper offers a preliminary exploration of the Corporate Social Responsibility (CSR) issues being addressed and reported by some of the UK's leading construction companies. The paper begins with a short discussion of the characteristics and origins of CSR and this is followed by brief outline of the construction industry and some of the challenges it is currently facing. The empirical information for the paper is drawn from the CSR reports and information posted on the World Wide Web by some of the leading construction companies. The findings reveal that each of the companies has its own approach to CSR and that there are substantial variations in the nature and the extent of the reporting process. More specifically the paper focuses upon six sets of CSR issues namely those relating to environment; health and safety; human resources; supply chain management; customers and communities; and governance and ethics. More generally the paper suggests that although construction companies report their recognition of the importance of CSR and their commitment to integrate it within their businesses they make relatively limited use of Key Performance Indicators and have low participation rates in general benchmarking exercises.
\end{abstract}

Keywords: Corporate Social Responsibility, UK Construction Industry, Stakeholders.

\section{Introduction}

Within the last decade 'Corporate Social Responsibility' (CSR) has been gaining momentum across the business community and it is seen to be increasingly high on boardroom agendas. Within the UK the construction industry makes a major contribution to the economy, to the social fabric of the country and to the creation of new environments. The larger firms within the industry increasingly recognise the impacts they have on the environment, on society and on the economy. They are increasingly keen to communicate their commitment to CSR to their shareholders, their customers, and their employees and to the public at large and to government. This case study offers a preliminary exploration of the CSR issues currently being addressed by some of the UK's leading construction companies.

\footnotetext{
* Professor, Deputy Dean, The Business School, University of Gloucestershire, The Park, Cheltenham, UK, (pjones@glos.ac.uk).

** Research Administrator, The Business School, University of Gloucestershire, The Park, Cheltenham, UK, (dcomfort@glos.ac.uk).

*** Professor, Head of Geography, School of Technology, University of Glamorgan, Pontypridd, Wales, UK, (dhillier@glam.ac.uk).

Članak primljen u uredništvo: 7.2.2006.
} 


\section{Corporate Social Responsibility}

CSR is concerned with the integration of environmental, social and economic considerations into business strategies and practices. That said there seems to be no universally agreed definition and Frankental (2001) has argued that 'CSR is a vague and intangible term which can mean anything to anybody, and therefore is effectively without meaning' and the UK's Confederation of British Industry (2001) has argued that 'CSR is highly subjective and therefore does not allow for a universally applicable definition'. However different organisations have framed a variety of definitions. The Commission for the European Communities (2001) defines CSR as ' $a$ concept whereby companies integrate social and environmental concerns in the business operations and in their interactions with their stakeholders on a voluntary basis'. For the Commission of the European Communities this means not just fulfilling legal responsibilities but also going beyond compliance to embrace wider social, environmental and economic goals. The World Bank (2004) defines CSR as 'the commitment of businesses to contribute to sustainable economic developmentworking with employees, their families, the local community, and society at large to improve the quality of life, in ways that are good for business and good for development'. According to Wood (1991) 'the basic idea of CSR is that business and society are interwoven rather than distinct entities.' More generally a distinction has been drawn between CSR seen as philanthropy as opposed to CSR as core business. In the former companies conduct their business unfettered by wider social concerns and then make charitable donations to selected worthy causes while in the latter the accent is upon operating the core business in a socially responsible way which seeks to enhance the competitiveness of the business and maximise the value of wealth creation to society.

In some ways the underlying concept of CSR has a long history. In outlining the growth of CSR, Hopkins and Crowe (2003) for example, suggest that there has always been a tension between business and social goals and they cite the power of the craft guilds in the Middle ages, the slave trade and the struggles to improve living and working conditions in Britain's rapidly growing towns cities during the nineteenth century, as graphic evidence of these tensions. Turning to more recent times Marlin and Marlin (2003) have identified three phases in the development of what they call 'CSR reporting'. The first phase dating from the early 1970's was seen to be composed of advertisements and annual reports which focused upon environmental issues but which were not linked to corporate performance. The second phase in the late 1980's was characterised by the introduction of social audits, which examined the performance of companies in the areas of social responsibility with respect to communities, employees, customers, suppliers and investors. Ben and Jerry's are cited as pioneering this approach with the Body Shop and Shell Canada being other early examples of companies adopting a similar approach. The third phase dating from the late 1990's saw the strengthening of social auditing through the introduction of externally set and certified standards.

A variety of factors are cited as being important in building the current momentum behind CSR. Ernst and Young (2002) suggest that five key drivers have influenced the increasing business focus on CSR viz. greater stakeholder awareness of corporate ethical, social and environmental behaviour; direct stakeholder pressures; investor pressure; peer pressure and an increased sense of social responsibility. The 
European Commission (2002) argues that CSR has gained increasing recognition amongst companies as an important element in new and emerging forms of governance because it helps them to respond to fundamental changes in the overall business environment. These changes include globalisation and the responsibilities companies feel the need to address as they increasingly source products and services in developing countries; the issues of image and reputation, which have become increasingly important elements in corporate success; and the need for companies to recruit and retain highly skilled personnel. Girod and Bryane (2002) adopt a strategic marketing perspective arguing that CSR is 'a key tool to create, develop and sustain differentiated brand names'. National and supranational governments have also been active in promoting CSR. The European Union, for example, promoted CSR in all member states and the UK Government has emphasised its ambitious vision for CSR.

The business case for CSR is seen to focus on a wide range of potential benefits. These include improved financial performance and profitability; reduced operating costs; long-term sustainability for companies and their employees; increased staff commitment and involvement; enhanced capacity to innovate; good relations with government and communities; better risk and crisis management; enhanced reputation and brand value; and the development of closer links with customers and greater awareness of their needs. At the same time there are those who would champion the case against companies integrating CSR into their core business. Such arguments might follow Friedmann (1982) in affirming that 'there is one and only one social responsibility of business-to use its resources and engage in activities designed to increase its profits so long as it stays within the rules of the game, which is to say engages in open and free competition without deception or fraud.' Henderson (2001) has argued that seemingly growing business commitment to CSR is 'deeply flawed' in that 'it rests on a mistaken view of issues and events and its general adoption by business would reduce welfare and undermine the market economy.'

CSR is characterised in a number of ways. The Commission for the European Communities (2001), for example, identifies an internal and an external dimension to any company's approach to CSR. The former concerns socially responsible practices within the company while the latter extends beyond the company into the local community and beyond and involves a wide range of external stakeholders. The internal dimension is seen to embrace the management of human resources; health and safety at work; adaptation to change; and the management of environmental impacts and natural resources. The management of human resources, for example, would include encouraging diversity within the workforce, responsible recruitment practices, equal pay and career prospects for women, profit sharing schemes and providing an environment that encourages lifelong learning. In a similar vein the management of environmental impacts and natural resources has focused upon reducing the consumption of resources, polluting emissions and waste. The external dimension is wide ranging and includes investors, local communities; business partners, suppliers and consumers; human rights; and global environmental concerns. CSR, for example, puts the onus on companies to provide products which customers want in an efficient, ethical and environmentally responsible manner. CSR is also seen to have a strong human rights dimension, which extends throughout the supply chain and thus increasingly has not just a national but also a global reach. 


\section{The UK Construction Industry}

The construction industry is a large and diverse component of the UK economy and embraces a wide range of businesses including building contractors, quarrying firms, products producers, builder's merchants and professional services. Estimates suggest that the industry broadly defined includes some 350,000 firms and that it employs almost 3 million people (Construction News 2005). Building contractors are in many ways at the visible heart of the construction industry and in 2005 some 170,000 firms generated some $£ 80,000$ million (at 2000 prices) in annual output and employed approximately 1.81 million people (Department of Trade and Industry 2005). The Department of Trade and Industry identifies a number of sectors of construction activity namely public housing; private housing; infrastructure; other public non-housing; private industrial; and private commercial and makes the distinction between 'new work' and 'repair and maintenance'. The volume of construction output is briefly summarised in Table 1, which indicates that the new private commercial work, private housing repair and maintenance, private maintenance work and new private housing are the four largest sectors accounting for almost $60 \%$ of all output. The overall volume of output has increased relatively steadily over the past five years from $£ 69,294$ million in 1999 to $£ 80,240$ million in 2004. The majority of the 170,000 construction firms are small, 93\% of firms on the Department of Trade and Industry's register have less than 14 employees while the 139 firms with over 600 employees account for less than $0.1 \%$ of all firms yet they are responsible for just over $25 \%$ of all construction output (Department of Trade and Industry 2004).

While each sector of construction activity has its own internal business and technical characteristics, agendas and challenges it is possible to identify a number of common general issues, which bring construction into the wider social realm. These include the nature and status of construction employment, health and safety, environmental concerns, relationships with communities, supply chain relationships, partnering, international ventures and public relations. The majority of building firms rely on a nominally self-employed labour force and the past two decades have witnessed a substantial increase in subcontracting in construction. Such subcontracting, although seen by many firms as an efficient use of labour, creates significant problems for innovation and training. The vast majority of self-employed workers are not in a position to be able to invest in their own training, site-based training is becoming increasingly rare and the numbers of apprentices and trainees are declining. In August 2005 the Chartered Institute of Building (2005) for example, reported that over $90 \%$ of its members were anticipating a skills shortage beyond 2005 and the prime cause of this shortage within the construction industry was seen to be the industry's poor image and greater competition from more attractive sectors of the economy. At the same time there are gender equality issues in that females comprise just below $10 \%$ of those working in the construction industry. Health and safety are major causes of concern within the construction industry. While the statistics vary from year to year, fatal accidents to workers are generally much higher than in any other industry and falls from height and the management of site transport and equipment are the main causes of fatalities. Occupational ill health is also a major problem and here the main risks are from manual handling, Hand-Arm Vibration 
Syndrome, high levels of allergic dermatitis and the legacy of past work with asbestos. Building projects can cause considerable disruption to local communities during construction and concerns are regularly expressed within communities about site cleanliness, noise, traffic management and the standards of dress and behaviour of the workers on site.

The construction industry has a significant impact on the both the natural and the built environment through energy and resource use, the production of waste materials, pollution and quarrying and sand and gravel extraction, and the associated impact on the landscape, and the creation of new buildings and roads. English Nature (2004), for example, argues that the construction industry has a number of adverse impacts on nature conservation including both the direct loss of Sites of Special Scientific Importance (SSSI) as well as indirect effects on SSSI's from adjacent developments. These indirect effects include disturbance, increased risk of vandalism, air and water pollution, fires and fly tipping and the displacement of individuals and populations of species leading to increased pressure elsewhere. English Nature suggest that these effects are often poorly addressed in Environmental Impact Assessments and their significance is often simply not recognised by decision makers. More generally the government has stressed that as the construction industry makes an important contribution not only in the use and management of resources but also in shaping their use in everyday life it also has a major role to play in working towards more sustainable consumption and production.

Managing the supply chain has long been a cause of economic and operational concern within the construction industry but many companies are coming under increasing pressure to ensure that their suppliers are meeting their social, environmental responsibilities. In a similar vein the UK construction industry has a long record of working overseas and this export business is worth some $£ 10$ billion per annum but many of the contracts won by the large construction companies now need to publicly demonstrate that the winning of such overseas contracts, the employment and heath and safety conditions on site and the social and environmental impact of construction project meet acceptable international standards. More generally the construction industry has a key role to play in society in providing a better built environment but it faces a major public relations challenge in that it widely perceived to be socially unimportant and to be 'dirty dangerous and old fashioned' (Department of Trade and Industry 2002).

\section{CSR Overview}

In an attempt to review the extent to which, and what, CSR agendas were being pursued within the construction industry the authors undertook an Internet search, via the Google Search Engine, of all the companies listed in the Guardian newspaper's 'London Prices' on August $17^{\text {th }} 2005$. This search, undertaken during the period 03.09.05 to 30.09.05 simply involved entering each of the listed companies' names and the words 'Corporate Social Responsibility'. Of the 37 companies listed 32 had posted some commentary about their approach to CSR but there was considerable variation in the volume and the detail of this information. Thus while some construction companies provide substantial and dedicated CSR reports, others include CSR information within their annual reports while others provide some limited information on CSR issues on their general company web sites. Bellway, for example, 
produced a 31 page 'Corporate Social Responsibility Report' while similarly titled reports produced by George Wimpey, Balfour Beatty and Barratt, ran to 28, 26 and 48 pages respectively and Persimmon Homes provide an interactive web based report. A number of companies including Costain, Mowlem, Henry Boot and Taylor Woodrow, devote a relatively small number of pages in their annual reports to CSR issues and agendas while others including Westbury and Redrow provide some limited CSR information on their company website.

Those construction companies that provide dedicated CSR reports claim to recognise the growing importance of CSR and to be working to integrate CSR agendas into their core business activity. Barratt, for example, emphasises that 'the company continues to embrace CSR and we are actively working to integrate it as part of our normal business operations.' In a similar vein Persimmon Homes stress that it continues 'to be committed to the concepts of CSR' and recognises that CSR issues 'have the potential to affect our business performance in both the immediate and the longer term and that they extend into almost every aspect of our business.' Costain claims that it 'demonstrates its corporate responsibility in many ways' and that CSR 'is integral to good business management.' This claimed commitment to CSR can also be identified in those construction companies which provide more limited CSR information in their annual reports or on their company's websites. Redrow, for example stress that developing and demonstrating a sense of corporate social responsibility is a key element in the company's business strategy while Taylor Woodrow 'recognises that the various elements of CSR are of increasing importance to our stakeholders and fundamental to the achievement of our business objectives.'

Construction companies report on CSR issues and agendas under a variety of different headings. Balfour Beatty for example, uses the following headings 'Safety', 'Occupational Health', 'Environment' and 'Social', George Wimpey uses 'Health and Safety', 'Environment', 'Community', 'Employees', 'Customer Care' and 'Supply Chain Management' while Bovis Homes lists 'Sustainable Development', 'Environmental Management', 'Health and Safety Management', 'Research and Development', 'Social and Ethical Conduct' and 'Human Resources'. In this paper six principal headings, namely Environment; Health and Safety; Human Resources; Supply Chain Management; Customers and Communities; and Governance and Ethics are used in an attempt to capture CSR agendas as reported by the construction companies but it is important to note that there is some inevitable overlap between these headings.

\section{Environment}

Environmental issues loom large in the CSR agendas being addressed by construction companies. These issues include energy and water use, climate change, environmental impact, waste management and recycling, transport, land use and planning, remediation, biodiversity and sustainability. George Wimpey, for example recognises that house builders have a major impact on the environment, both within the communities in which they operate and further afield and the company aims to minimise adverse impacts while striving to protect and enhance the natural environment. In evidencing these commitments the company claims that in the UK in $200468 \%$ of the homes they built were on brownfield sites and $65 \%$ of all waste was recycled, that a 'Site Specific Environmental Action Plan' which identifies and seeks 
to manage ecological issues is produced before construction work begins and that the company's staff and its sub-contractors receive extensive environmental training. In a similar vein Bellway report that it is keen to reduce potential environmental impacts. To this end the company claims to have developed specific capabilities, for example, in the remediation and development of brownfield sites including redundant hospitals, disused airfields, power stations and disused rubber and lead works. At the same time the company claims where its sites display significant ecological resources these are preserved and enhanced wherever possible. While the company devotes over half its report to environmental issues it also notes that its environmental commitments are subject to 'economic conditions'.

Crest Nicholson addresses a number of issues under the banner of 'Environmental Stewardship.' The company reports progress, for example, on a number of initiatives, including the installation of high energy efficient condensing boilers, envelope insulation and lighting designed to increase energy efficiency, on plans to reduce local car use, the installation of zero ozone depleting products in roof spaces, walls and pipe voids and the switch to efficient water taps and showers in some $85 \%$ of open market housing, but only $15 \%$ of affordable housing, in 2004. Balfour Beatty stresses their commitment to operating in an environmentally responsible manner and the company looks to assess its environmental management by monitoring a number of indicators including the proportion of the business with formal environmental systems certified to ISO 14001; progress in the independent annual benchmarking assessment conducted by the consultants 'csr-network'; the company's rating in the Business in the Environment Index; environmental incidents classified by severity; and environmental notices, prosecutions and convictions. In 2004, for example the company achieved ISO 14001 certification for $87 \%$ of its UK business by turnover and in the Business in the Environment Index the company increased its score its score to $82 \%$ from $45 \%$ in 2001.

\section{Health and Safety}

Health and safety are major issues for all construction companies. George Wimpey, for example, stresses that health and safety is its highest priority and that it takes its responsibilities in this area extremely seriously. The company's priorities here are listed as being accident prevention; health and safety management; employee and contractor training; designing for safety; site inspection and audits; and engaging with stakeholders. Safety is taken into account at the design stage of all new house types and if a new design cannot be built safely it is rejected. Extensive health and safety training is provided for the company's staff and for sub contractors and regular campaigns and safety awards are run to promote best practice. The company reports that in 2004 it revised and updated its trade risk assessments for key activities on site. This involved identifying the hazards associated with each task and improving control measures to reduce risks and this information was made available not only internally within the company but also to all relevant contractors. Towards the end of 2004 the company started work on a major safety awareness campaign designed to strengthen and confirm a culture of safety which, in part, encourages all people on site to take greater responsibility for their own and others' safety. That said the company reports that however much emphasis it puts on safety and however much training it undertakes, operatives still take shortcuts that put themselves and others in danger to save time and effort. More positively Mowlem reports a 20\% reduction in 2004 in the 
number of accidents reported, in the accident frequency rate and in major injuries and claims that these reductions show the company to be well below construction industry averages in all the sectors in which it operates.

While some construction companies focus jointly on safety and health issues within their CSR reports deal with them separately. Balfour Beatty, for example, designates occupational health as one of the four themes within its 'Safety, Environment and Social Report' for 2004. Here the company's aim is to ensure that no harm comes to its employee's health as a result of its activities. It claims to have a good record in addressing specific occupational health conditions and many examples of good occupational health practice covering managing asbestos, manual handling, skin conditions arising from exposure to substances, noise exposure, vibration risks and stress. Vibration and noise risks, for example, have been a priority for several years and a task group has been disseminating good practice and testing new 'low vibration' tools. The company also looks to measure sickness absence data in order to provide a view of the nature and scale of occupational health problems amongst its workforce. That said while the company has been able to measure data on total absence relatively robustly it has found it more difficult to measure absence due to work-related ill health. In part this reflects definitional difficulties in deciding whether ill health is work related or has a more general cause and in part it reflects the practical difficulties in collecting this data from employees on site.

\section{Human Resources}

There is a general recognition that human resource management is relatively poorly developed within the construction industry and in part this reflects the fragmentary structure of the industry. That said many construction companies seem to be increasingly recognising the importance of their human resources in helping them to achieve and retain competitive advantage. Bovis Homes Group, for example, 'recognises that its employees are its most valuable asset and that it is their knowledge and skills and expertise that determine the success of the Group.' As such the company claims to endeavour to treat all its employees in an ethical, socially responsible and equitable manner. The aim is to be 'an employer of choice and to attract and retain the best staff available.' Many other companies also report these general commitments and sentiments. Gleeson stresses its commitment to equal opportunities and its Equal Opportunities Policy, updated in 2004, looks to ensure that job applicants and employees do not receive less favourable treatment on grounds of age, race, colour, religious beliefs, political opinions, ethnic origin, nationality, marital/parental status, gender, sexual orientation or disability; the workforce is selected solely on merit and that it reflects, where practicable, the diversity of the working population; the working environment is free from harassment, discrimination and intimidation; and that all employment conditions and job requirements reflect the company's commitment to equal opportunities.

Some companies are keen to report their commitment to training. Barratt, for example, claims not only to be committed to the provision of training and development which addresses the requirement of the workforce at all levels within the company but also the largest apprentice training programme in the UK's housebuilding industry. This programme provides key skills training over a period of three years in bricklaying, carpentry and plumbing. Crest Nicholson reports operating 
a continuous programme of training need analysis to identify the skills and knowledge bases required by its employees. In 2004 the company began to record all its training activities and these activities are systematically evaluated to examine if and how learning is transferred to the workplace. In Birmingham the company has worked in partnership with the Construction Industry Training Board, Optima Community Association and South Birmingham College to develop construction skills training courses and it has introduced students to its sub-contractors and monitors their progress in acquiring vocational qualifications. The company also reports planning to introduce a structured learning programme for apprentices, student placements and graduates in 2005 and to increase the number of formally qualified site agents.

A number of construction companies report initiatives designed to improve communications with their employees. George Wimpey, for example, reports the introduction in 2004 of national and regional initiatives to tackle this very issue. These include a transparent procedure for the internal advertising of all job vacancies, and the launch of an induction CD-ROM to ensure that all employees receive complete and consistent information on the company and its practices and procedures and a statement of the company's annual performance appraisal process. Bovis Homes Group argues that 'communication and engagement with employees are key to optimum performance and to the success of the business.' The company reports that regularly updated handbooks, departmental and regional staff meetings, conferences, maintained notice boards and an employee magazine entitled 'Update News' are all important in promoting understanding and involvement. Barratt reports a review of its employee communications processes and the introduction of a Wide Area Network that will enable the company to establish an intranet, which it believes, will enhance its communications capability.

\section{Supply Chain Management}

While a variety of supply chain relationships are an integral part of the construction industry discussions of these relationships are not a major element in CSR reports and information. The issue is rarely mentioned in many CSR reports and in others it receives scant treatment. George Wimpey, for example, lists it as one of six CSR issues in their 28 page annual report but devotes just three lines to it and simply intimates that the company has explored CSR related supply chain issues, defined the criteria for decision making, highlighted best practice and set targets for 2005. Gleeson notes that all its suppliers and contractors are subject to environmental screening and a suite of specific 'environmental toolbox talks', ranging from the disposal of non-hazardous waste to wildlife and archaeology, are delivered to contractors where appropriate. In a similar vein Redrow simply report that it has 'clearly stated terms and conditions of trading for all our suppliers and subcontractors and have developed long standing relationships with many of them, which assist in the development of both businesses.'

Crest Nicholson, on the other hand, reports its commitment to 'develop long term non-adversarial partnerships with our contractors and suppliers' and the company identifies three significant contractor and supplier issues for improvement viz. resource impacts; contractor/supplier partnerships and assessment; and waste management. In seeking to effect improvements in the supply chain the company is often looking to address a number of the issues it has been addressing within their 
own company. In focusing upon resource impacts, for example, the company has reduced its supply chain transport and paperwork impacts by using a single source multiple product supplier and this in turn, the company claim has contributed to lessening traffic congestion and the associated noise, vibration and emissions to the communities surrounding its development sites. In addressing contractor /supplier partnerships the company's objective is to form partnerships for sharing the economic benefits of improved environmental and social practices and innovation. The company reports adding environmental selection procedures in 2004 and a sample of over 100 questionnaires on policy, responsibility, compliance, waste management, production selection and emergency preparedness were analysed. The results of this sample survey revealed, for example, that $81 \%$ of subcontractors/suppliers had a manager assigned with environmental responsibilities, $68 \%$ had implemented relevant environmental impact controls and only $3 \%$ had been found to be non-compliant with an environmental regulation during the previous three years.

\section{Customers and Communities}

Construction companies' customers, the communities in which construction companies work and the communities they create feature in many CSR reports. George Wimpey, for example, aims to 'offer our customers unrivalled and consistent quality of product and service' and the accent is on making 'the process of selecting, purchasing, decorating and moving into a new home as smooth and uncomplicated as possible.' The company reports that its priorities are a customer service culture; customer satisfaction; fair treatment of customers; quality build and finish; handling complaints; and communicating with customers. Crest Nicholson highlight their performance in the 2003 National Customer Satisfaction Survey for new homes and reports above industry average ratings on 'quality of home', which incorporated value for money, construction, finish and overall satisfaction and 'service', which focused upon the condition of the property on moving-in day, the likelihood of recommending the company to other people and overall satisfaction. The company also stresses its commitment to safeguarding the privacy of potential customers who visit its website by only using customers' information to respond to their requests for brochures or to communicate information about developments that may be of interest to them.

A number of construction companies emphasise the commitments and responsibilities they have to the communities in which they work. Persimmon Homes reports a bespoke approach to community consultation and stresses that it needs to be adaptable when understanding the needs of local people. The company argues that not only does it contribute to a local area through the creation of new houses and inclusive communities but it can also often contribute to the local economy through the creation of new jobs, by placing orders with local businesses and through the development of local infrastructure. Further the company claims that it is this local focus that differentiates it from its competitors and that its staff have developed important working relationships with local planning authorities and community groups. Crest Nicholson look to capture the spirit of commitment to local communities in the sub title of their 2004 Corporate Social Responsibility Report, which is entitled 'Listening to the communities we build.' The company's community strategy embraces 'creating long term stewardship and management of communities; partnering and engaging in full community processes; and commitment to the government's sustainable communities agendas.' At the same time a number of 
construction companies report their commitment to be 'good neighbours'. Taylor Woodrow, for example stresses that one of its CSR priorities is to minimise the effects of its development activities on those living nearby. It believes that good communication with neighbours is particularly important and the company often uses 'project newsletters' to enhance the communication process. The company also reported doubling the number of its sites participating in the 'Considerate Constructors' scheme during 2004.

More generally some construction companies report their involvement in wider community initiatives and their charitable contributions to local communities. In 2003 Gleeson introduced a scheme providing up to three days paid leave per year to enable its employees to participate in approved local community projects. Such activities can involve care of the aged and infirm, work with schools, hospitals, and community centres and work with disadvantaged members of communities. The company also supports a range of events including race days, raft races and marathon runs to raise money for local charities and works in partnership with the Surrey Wildlife Trust on a variety of countryside and wildlife conservation projects. In a similar vein Galliford looks to make a positive impact within communities. The company reports working with schools to promote children's life skills and it encourages employees to take part in charitable and community based events.

\section{Governance and Ethics}

A minority of the construction companies included in this study explicitly report on governance and on the ethical conduct of their business operations. Some companies address the issue in a summary form while others provide a greater level of detail. On the one hand George Wimpey, for example, simply reports that the company is committed to achieving high standards of corporate governance and that during 2004 it complied with the provisions of the Combined Code on Corporate Governance. In a similar vein Bellway recognises the importance of maintaining and achieving a high standard of corporate governance. Persimmon Homes reports its support for the highest standards of corporate governance and that its Board has overall responsibility for the identification, evaluation and management of risk.

On the other hand Bovis Homes, Crest Nicholson and Gleeson, for example, provide more detailed commentary on their approach to corporate governance. Bovis Homes reports its recognition that strong corporate governance is an essential element for successful business management and stresses its commitment to such governance including the requirements set out in the 2003 Combined Code on Corporate Governance. The company emphasises that its Board's role is to provide entrepreneurial leadership within a framework of prudent and effective controls and to manage the business successfully and to determine business strategy. Risk identification and management is an important feature of the company's system of internal control and ten key risks are designated in the report. These include adopting the wrong strategy in relation to the economic cycle; a loss or unacceptable profit incurred from the development of landholdings; entering into business risk which does not increase shareholder value; the loss of key personnel which leads to an impairment of trading ability; and the employment of untried or unproven technologies. The company stresses that all the company's employees have a responsibility for 'early warning' mechanisms and for the anticipation, identification, 
assessment and minimisation of such risks. Gleeson also stress its commitment to the Combined Code on Corporate Governance and provides details of the structure and workings of the company's Board, the election of Directors, the workings of the Remuneration and Audit Committees and internal control and risk management.

Bovis Homes was the only construction company to formally address ethical issues as part of its CSR reporting. The company's 'objective at all times is to behave with integrity and operate in a socially responsible and ethical manner respecting the dignity and rights of individuals and avoiding conflict of interest.' To this end the company has drawn up an 'Ethical Code of Conduct' which covers a range of commitments including respecting the rule of law and complying with regulations and legislation, never to knowingly engage in areas of business activity incompatible with social inclusion and not to participate in or condone corrupt or unacceptable business practices. At the same time the company also stresses that it will not have any knowing involvement in a wide range of practices that may result in involvement in a social or ethical dilemma. These practices are listed as including animal testing, abortion clinics, gambling, genetic engineering, intensive farming, pornography, ozone depletion, third world exploitation and nuclear power. All the company's employees are inducted into and required to understand and act in accordance with the company's ethical and social standards and the company's 'Conflict of Interest Policy' stipulates that employees are not permitted to engage in other business activities without written consent. The company report no breaches of its ethical code of conduct during 2004.

\section{Discussion}

The vast majority of the construction companies included in this paper claim to be committed to integrating CSR agendas into to their core business activities. This commitment raises a number of more general issues that merit some discussion. In addressing CSR issues construction companies are not only recognising that the construction industry is operating within a rapidly changing environment but also responding to pressure from a variety of stakeholders including Government, investors, shareholders, trade unions and customers and these pressures are manifest in number of ways. The government, for example, are major direct and indirect investors in, and commissioners of many construction projects. As such they are in a position to promote their vision that CSR is good for society and good for business. Investors and investment fund managers are increasingly attracted to construction companies, which are able to demonstrate that they are making a positive contribution to society. As customers become both increasingly informed and demanding so those companies that can demonstrate their commitment to customers and to their customers' values may be able to achieve and retain competitive advantage within the marketplace. At the same time business imperatives seem to be just as important drivers of CSR as commitment to corporate responsibility. Thus while many of the environmental initiatives addressed in CSR reports and information are designed to reduce energy and water use and waste generation, for example, they also reduce costs. In a similar vein health and safety issues, focusing for example on the creation of a safer working environment accident prevention, reductions in absenteeism and staff training designed to enhance health and safety awareness and to spread good working practices will help to ensure that contracts are completed on time, to budget and to the client's specifications. 
In some ways the CSR reports and information posted on the World Wide Web by construction companies is largely, though far from entirely, aspirational. However if, as seems likely, the focus on CSR continues to gain momentum then companies will need to be increasingly vigilant and transparent in demonstrating their CSR credentials. To date construction companies report only limited use of Key Performance Indicators (KPI's) to measure their CSR performance. Bovis Homes, for example uses a number of short case studies to illustrate their CSR commitments but make little attempt to measure or benchmark their performance. While Gleeson reports a number of objectives and targets these often lack detailed specificity. Balfour Beatty reports employing the consultants $\mathrm{Sd} 3$ to carry out an independent assurance on its CSR report. Sd3's validation statement found the environmental reporting system to be sufficiently robust to provide a fair representation of the company's performance but that the environmental reporting processes were not always well embedded at the operational level and expressed some similar reservations about the company's safety reporting.

Barratt, George Wimpey and Crest Nicholson, for example, report on their use of KPI's. Barratt, recognises that 'KPI's are an essential tool in the measurement of the performance of an organisation, and allow it to be benchmarked in relation to the rest of the industry' and it reports identifying a target date to agree a set of KPI's within the company and with its suppliers. George Wimpey identified KPI's for each of Governance; Health and Safety; Environment; Employees; and Customer Care. Annual target setting and continuous monitoring and review of these KPI's will be important in allowing the company to chart its progress in meeting CSR goals and in demonstrating the achievement of these goals to stakeholders. Even here though, there is little explicit detail on the nature or independence of the verification data for these KPI's. Crest Nicholson devote some $25 \%$ of their 58 page CSR report to KPI's which also includes an independent verification statement. Currently very few construction companies report participating in more general attempts to measure and benchmark their CSR performance and only three construction companies were listed, for example, in the Business in the Community Corporate Responsibility Index 2004.

The construction industry operates within a fiercely competitive environment and all companies need to balance their seemingly growing CSR commitments against their commercial goals. Indeed some companies openly acknowledge the importance of such goals and qualify their CSR commitments as being conditional upon what in one case is stated as 'economic conditions'. The tensions between CSR and commercial goals may merit very limited attention in CSR reports and while the companies may wish to portray CSR as integral to their business such harmony may not always be reflected at the operational level or in relationships with suppliers and sub-contractors. Here site managers, for example may face tremendous pressures in securing and retaining labourers and skilled craftsmen, in coping with unexpected site conditions and poor weather, in co-ordinating supply deliveries, in communicating with the relevant professionals, in working within regulatory frameworks and in meeting deadlines. In such situations complying with CSR guidelines and collecting data to measure CSR performance against targets may be luxuries many site managers feel they cannot afford. It would be foolish to pretend that senior executives within construction companies do not recognise these pressures and the operational and 
commercial imperatives that give rise to them and as such they seem likely to form a continuing challenge for those charged with delivering CSR on construction sites.

\section{Conclusion}

The majority of the major UK construction companies have their own specific approach to CSR but there is considerable variation in the nature and extent of the reporting process and in the CSR issues and agendas addressed in the reporting process. An explicit and sustained focus on environment, health and safety and human resources is common to most companies, supply chain management, customers and communities generally receive more selective and limited treatment and governance and ethics merit much more limited attention. While construction companies report their recognition of the importance of CSR and their commitment to integrate it within their businesses their relatively limited use of KPI's and much more limited participation in more general benchmarking exercises suggests that they may find it difficult to convince increasingly demanding and well informed stakeholders that their CSR commitments are genuine and independently verifiable. Finally it must be stressed that in many ways the CSR reports reviewed here emphasise the construction companies' aspirations, which may not always be fully reflected in everyday operations within an often fiercely competitive business environment. Within the construction industry the tensions between these aspirations and the realities of CSR will provide fertile ground for future enquiry and research. 
Table 1.

Volume of Construction Work by Type of Work 2004

\begin{tabular}{|l|c|}
\hline Type of work & $\begin{array}{l}\text { Value (£ million) at } \\
\text { constant (2000) prices }\end{array}$ \\
\hline & 1,967 \\
\hline New Public Housing & 10,778 \\
\hline New Private Housing & 5,852 \\
\hline Infrastructure & 8,074 \\
\hline New Public Work Excluding Infrastructure & 3,371 \\
\hline New Private Work Excluding Infrastructure & 12,757 \\
\hline New Private Commercial Work Excluding Infrastructure & $\mathbf{4 2 , 7 9 9}$ \\
\hline All New work & 6,845 \\
\hline Public Housing Repair and Maintenance & 12,418 \\
\hline Private Housing Repair and Maintenance & 6,643 \\
\hline Other Public Repair and Maintenance & 11,534 \\
\hline Other Private Repair and Maintenance & $\mathbf{3 7 , 4 4 1}$ \\
\hline All Repair and Maintenance & $\mathbf{8 0 , 2 4 0}$ \\
\hline All Work & \\
\hline & \\
\hline
\end{tabular}

(Source: Department of Trade and Industry News Release 'Output and Employment in the Construction Industry Second Quarter 2005' 2.9.2005)

\section{REFERENCES}

Chartered Institute of Building (2005) 'News Release: CIOB Reveals Results From Skills Shortage Survey', www.prnewswire.co.uk/cgi/news/release?id=151701

COMMISSION OF THE EUROPEAN COMMUNITIES (2001) 'Promoting a European framework for Corporate Social Responsibility', http://europa.eu.int/eurlex/en/comgpr/2001/com2001_0366en01.pdf

COMMISSION OF THE EUROPEAN COMMUNITIES (2002)

'Communicating From the Commision concerning Corporate Social Responsibility: A business contribution to Sustainable Development' http://europa.eu.int/comm?employment_social/soc-dial/csr/csr2002_en.pdf

Confederation of British Industry (2001) 'CBI response to the European commission green paper on promoting a European framework for corporate social responsibility',www.europa.eu.int/comm/employment_social/soc-

dial/csr/cbi_uk_en011219.htm

Construction News (2005) 'Industry Structure', http://www.cnplus.co.uk/vital_statistics/industry_struct/

Department of Trade and Industry (2002) 'Rethinking Construction Innovation and Research: The Fairclough Report', www.dti.gov.uk/construction/concl.htm 2004',

Department of Trade and Industry (2004) 'Construction Statistics Annual www.dti.gov.uk/construction/stats/constat2004.pdf?nourl=www.dti.gov.uk/publicatio ns/pdflink/\&pubpdfdload=04\%2F285 
Department of Trade and Industry (2005) 'Output And Employment In The Construction Industry Second Quarter 2005', www.dti.gov.uk/construction/stats/020905/pressrel020905.htm

English Nature (2004) 'Sector Analysis: Construction and Development', http://www.english-nature.org.uk/about/sector/construction.htm

Ernst \& Young (2002) 'Corporate Social Responsibility'

www.ey.nl/download/publicatie/doemload/c0rporate_social_responsibility.pdf

Frankental, P. (2001) 'Corporate social responsibility-a PR invention?', Corporate Communication: An International Journal, 6, 1, pp. 18-23

Friedmann, M (1982) 'Capitalism and Freedom', University of Chicago Press, Chicago.

Girod, S. and Bryane, M. (2003) 'Branding in European Retailing: A corporate social responsibility perspective', European Retail Digest, 38, 1-6

Henderson, D. (2001) 'The Case Against Corporate social Responsibility', Policy, 17, 2, pp.28-32.

Hopkins, M. and Crowe, R. (2003) 'Corporate Social Responsibility: Is there a Business Case?' www.accaglobal.com/pdfs/members_pdfs/publications/csr03.pdf

Marlin, A. and Marlin J. T. 'A brief history of social reporting' www.mallenbaker.net/csr/CSRfiles/page.php?Story_ID==857

The World Bank Group (2004) 'Corporate Social Responsibility' www.worldbank.org/developmentcommunications/where1/environment/csr.htm

Wood, D. J. (1991) ' Corporate social performance revisited', Academy of Management Review, 16, pp.691-718

\section{KORPORATIVNA DRUŠTVENA ODGOVORNOST I GRAĐEVINSKA INDUSTRIJA U VELIKOJ BRITANIJI}

\section{SAŽETAK}

Ovaj rad nudi preliminarni pregled Korporativne društvene odgovornosti (CSR) na koje ukazuju neke od vodećih građevinskih tvrtki u Velikoj Britaniji. Rad započinje kratkom raspravom o karakteristikama i porijeklu Korporativne društvene odgovornosti (CSR), čemu slijedi kratki pregled građevinske industrije te izazova s kojima se trenutno suočava. Empirijski podaci u radu su preuzeti iz CSR izvještaja i informacija objavljenih na Internetu od strane vodećih građevinskih tvrtki. Analizom se otkriva da svaka tvrtka ima vlastiti pristup Korporativnoj društvenoj odgovornosti (CSR) te da postoje značajne varijacije u prirodi $i$ obimu sastavljanja izvješća. Rad se pobliže usredotočuje na šest skupina pitanja povezanih s Korporativnom društvenom odgovornošću (CSR), točnije na one vezane uz okoliš; zdravlje $i$ sigurnost; ljudske resurse; upravljanje lancem dobavljača; kupce i zajednice; upravljanje $i$ etiku. Rad uglavnom sugerira da iako građevinske tvrtke jasno prepoznaju važnost korporativne društvene odgovornosti (CSR) $i$ vlastite obaveze da je uvedu u svoje poslovanje, relativno se ograničeno koriste Ključnim Indikatorima Performansi te slabo sudjeluju u općim «benchmark» izviješćima.

Ključne riječi: Korporativna društvena odgovornost, Građevinska industrija u Velikoj Britaniji, interesne skupine 
